\title{
NACHRICHTEN
}

\section{EU environmental legislation: Handbook for implementation soon available}

The European Commission has published a handbook for implementation of EU environmental legislation, aimed to "provide a planning framework and step-by-step guidance on the approaches and specific activities required to implement EC environmental legislation". The handbook provides:

- a series of overview chapters which set out a framework for planning the implementation of the legislation contained within that particular environmental sector;

- a series of fiches containing information and guidance about each legal act presented in the "Acquis guide";

- a reference source.

The handbook has been produced with support from the Environment Directorate-General in collaboration with the Phare-funded DISAE programme. However, the findings, conclusions and legal interpretations expressed within the document are not intended to reflect the European Commission's opinions or policies.

The handbook, presently in draft form, is aimed at officials (including legislators, civil servants, planners and environmental advisors, for example) in national, regional and local government agencies in the candidate countries who have responsibilities for the planning, management and implementation of environmental laws and programmes. It may also be of interest to other parties in the candidate countries in industrial and commercial sectors affected by the legislation as well as non-governmental organisations.

The handbook will be available online from:

http://europa.eu.int/comm/environment/enlarg/ handbook/handbook.htm

(Source: CORDIS focus) 